\title{
造船における溶接自動化の経済性*
}

寺井 清** 金谷交善** 中尾次 郎***

\section{Economic Aspects of Automation of Welding in Shipbuilding*}

by Kiyoshi Terai**, Fumiyoshi Kanatani** and Jiro Nakao***

\section{1.まえがき}

日本の造船界は過去において溶接技術の進歩を核とし て 2 回の技術革新の洗礼を受けてきた. その第 1 期は第 2 次大戦後米国より導入されたサブマージ・アーク溶接 法による自動溶接と高酸化鉄系の大径溶接棒による水平 スミ肉溶接の 2 つを主体として地上工程の合理化を計ろ うとするもので, これによりわれわれは造船界にいわゆ るブロック建造法なるプレハプの概念の導入に成功した 、また最近の第 2 期では筆者の提案による造船工程全般 にわたる溶接の自動化, 専用化の推進を動機とするもの で造船を construction type から production type に 発展させる努力が行なわれつつあり, なかであ筆者の造 船所は図 1 に示すようにそのリーダー・シップをにぎる 中心的存在の 1 つとなってきた. 本論文では筆者の造船 所におけるそれらの情況について大型船を具体例にとり

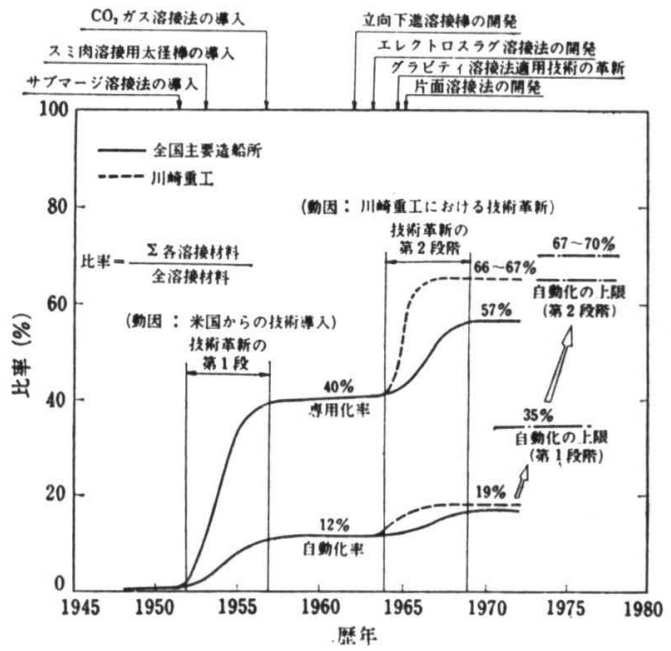

図一 1 造船における溶接技術の変遷

* 原稿受付 46 年 9 月 2 日（46年 4 月英国溶接学会主催国際シンボシ ウムに発表）

**正員 川崎重工業株式会社技術研究所 Member, Welding Research Dept. Kawasaki Heavy Industries, Ltd.

****崎重工業株式会社技術研究所 Welding ResearchDept. Kawasaki Heavy Industries Ltd,
溶接の自動化の方法と使用溶接材料の使用実績（重量 比）からみた自動化率ならびに自動化による節減工数と さらに自動化の問題点について述べたものである.

\section{2. 溶接の自動化}

\section{1 片面自動溶接}

この数年来片面自動溶接法の導入の機運は造船を中心 とする組立業界においていちじるしく高まりつつある. とくに造船の場合には現在多くの工場において広範な浸 透をみせており，地上の板つぎ工程における片面自動溶
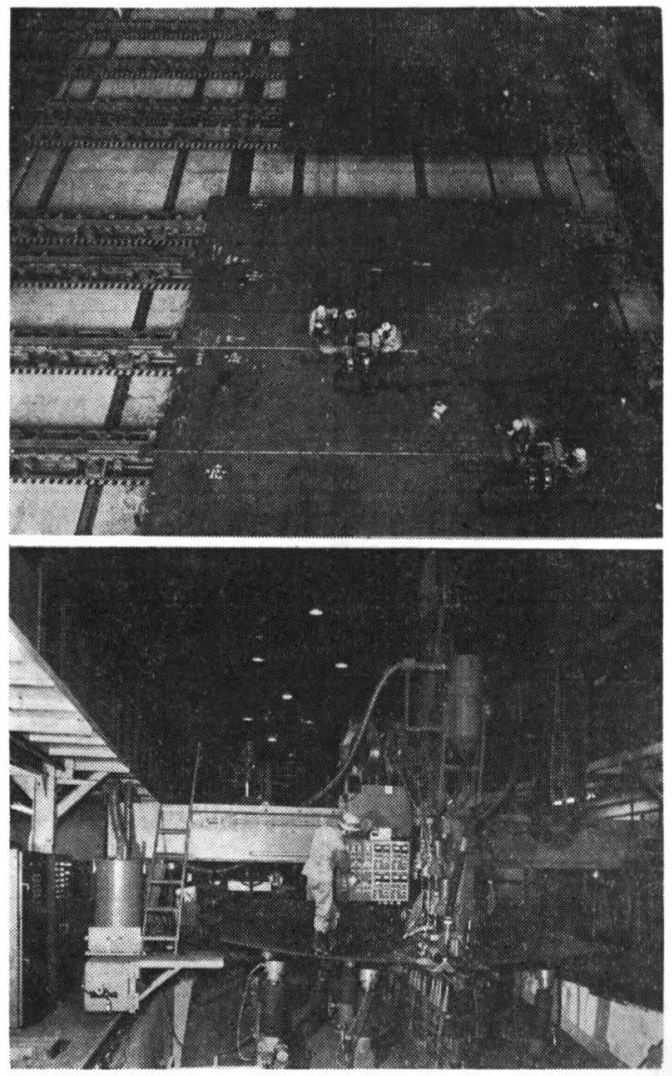

図一２地上の板継ぎ工程におけるアセンブリ・ラ イン型片面自動溶接装置例 (写真上は平板 の場合を, 下は曲り外板の場合を示す) 
接の実用化はもちろんのとと船台における各種の片面自 動溶接もすでに実施の段階に入っている：ての溶接法は コンベアなどの各種の付属機器を伴なった工場の生産シ ステム全体に関連するととろのアセンブリ・ライン型の あのと，船台上の最終組立工程での溶接を近代化する エレクション・ショイント型の 2 者に大別され，それ ぞれがさらに各種の方法に区分される：前者はブロック の板継ぎに使用されるが，との方法によって従来継手の 片側すなわちバッキング・パス側を溶接ののちパネル全 体を反転してしかるのち他の片側すなわち表面僋を溶接 した複雑な工程を直接化して単一工程にまとめることが できる、てれにはサブマージ・アーク溶接法が用いられ 地上組立工程における上部構造をのぞくすべての平板ブ ロックの板継ぎに適用されている．さらに筆者は曲りブ ロックの板継ぎに対してもポジショナーを用いててれの 被溶接面を継ね水平儌するととにより曲り外板の 全継手に片面自動溶接法の適用を研究中であり，近い将 来隹実用化できるみとおしを得ている（図 2 ). また後 者にはサブマージ・アーク溶接あるいは $\mathrm{CO}_{2}$ ガス・ア 一ク溶接法が用いられ，船台工程に扔けるフラットな主
板の板継ざ，ならびに船体平行部側外板㧍よび綎横隔壁 のロンジ・フレームに適用されるが，従来水平におかれ た板材同志の継手の片側はかならず熟練と忍耐を要する 上向溶接によらなければならなかったのが，乙の方法に よって下向溶接のみで行なえるようになった。

\section{2 立向自動溶接}

立向自動溶接は最初日本では1960年に造船部門に導入 された，大型船の側外板の現場継手にエレクトロスラグ 溶接法を適用したのが最初の例である。さらにその後 1966年には内部構造部材を対象とした消耗ノズル式エレ クトロスラグ溶接法も開発され，てれにより底部外板な らびに上甲板づきロンジ材の現場溶接の自動化が可能に なった．またての他の立向自動溶接として最近開発され たものに，ブロック組立工程においてトランス材とロン ジ材の取合個所となる立向スミ肉継手の専用自動溶接機 がある.との場合溶接法はノンガス・アーク溶接法を用 いている.

\section{3 その他の自動溶接}

その他の自動溶接法としては地上工程においてロンジ 材と主板の取合部水平スミ肉継手に適用されるサブマー

表一 1 巨大船建造に使用される溶接材料の使用比率の変䙴（川崎重工）

\begin{tabular}{|c|c|c|c|c|c|c|c|c|c|c|}
\hline \multirow{2}{*}{ 材 } & \multirow{3}{*}{ 溶 } & \multirow{3}{*}{ 工 程 } & \multirow{3}{*}{ 継手 } & \multirow{3}{*}{ 通 } & \multicolumn{6}{|c|}{ 溶接材 } \\
\hline & & & & & \multirow{2}{*}{ 1950以前 } & \multirow{2}{*}{$1950 \sim 1960$} & \multirow{2}{*}{$1960 \sim 1965$} & \multirow{2}{*}{$1965 \sim 1970$} & \multicolumn{2}{|c|}{ 1970以降 } \\
\hline & & & & & & & & & 第 1段階 & 殷 2 段階 \\
\hline \multirow[b]{5}{*}{ 自動溶接 } & サブーーシ & 地上 & 突合せ & 平板 ブアック & $0 \%$ & $11 \%$ & $12 \%$ & $\left(\begin{array}{c}13 \% \\
\left.\begin{array}{c}13 \% \\
\text { 而自動 } \\
\text { 令 }\end{array}\right) \\
\end{array}\right.$ & $13 \%$ & $13 \%$ \\
\hline & $"$ & $"$ & $" r$ & 曲リブロック & 0 & 0 & 0 & 3 & 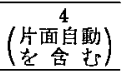 & 4 \\
\hline & $"$ & 船 台 & $"$ & 主板 & 0 & \multirow{2}{*}{1} & \multirow{2}{*}{1} & \multirow{2}{*}{1} & \multirow{2}{*}{1} & \multirow{2}{*}{1} \\
\hline & $\mathrm{CO}_{2}$ & $"$ & $"$ & $"$ & 0 & & & & & \\
\hline & $\# \rightarrow \vec{\nabla}-\dot{\prime}$ & 地 上 & ス令肉 & ロンシ・フレーA & 0 & 0 & 0 & 0 & 9 & 28 \\
\hline \multirow[t]{5}{*}{ 林 } & 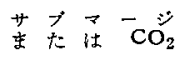 & 船 台 & 突合せ & $"$ & 0 & 0 & 0 & 1 & 1 & 1 \\
\hline & エレタトロスラグ & $"$ & $"$ & 側 外板 & 0 & 0 & 1 & \multirow{2}{*}{1} & \multirow{2}{*}{1} & \multirow{2}{*}{1} \\
\hline & $\begin{array}{l}\text { 消耗ノズル型 } \\
\text { エレクトロスラグ }\end{array}$ & " & $"$ & ロンジ・フレーム & 0 & 0 & 0 & & & \\
\hline & , & 地上 & xミ肉 & 枠租 & 0 & 0 & 0 & 0 & 6 & $18^{\circ}$ \\
\hline & そ $\quad$ 他 & 全工程 & $\begin{array}{l}\text { 조肉 } \\
\text { 笑合せ }\end{array}$ & - & 0 & 0 & 0 & 0 & 0 & $0 \sim 3$ \\
\hline \multirow{3}{*}{$\begin{array}{l}\text { 甫师型 } \\
\text { 寉接棒 }\end{array}$} & $\begin{array}{l}\text { E6020 または } \\
\text { E6027 }\end{array}$ & 全工程 & スミ肉 & グラビライ溶接法 & 0 & 28 & 28 & 28 & 19 & \multirow{3}{*}{$\begin{array}{l}\text { 自動溶接に } \\
\text { 国換する }\end{array}$} \\
\hline & $\mathrm{E} 6016$ (立何) & $"$ & $\begin{array}{l}\text { スミ肉 } \\
\text { 突合は }\end{array}$ & - & 0 & 0 & 6 & 18 & 12 & \\
\hline & $\mathrm{E} 6016$ （水平） & 船 台 & 突合せ & - & 0 & 0 & 0 & 1 & 1 & \\
\hline 自 & 動溶接材料お & び専 & 用型 材 & 料の合計 & 0 & 40 & 48 & 66 & 67 & $67 \sim 70$ \\
\hline
\end{tabular}

（注）表中の $0 \%$ の表示は沉用型溶接椿もしくは銈接の適用を $100 \%$ とする。 
ジのテク溶接法がある゙，ての場合ブロックの組立法は 口ッシ先付け法（いわゆるライシ.ウエルド方式）を採 用している。また曲った外板の板継ぎにるフラックスの 対傾斜性が改善されてサブマージ:ア一ク溶接法が，傾 斜角 $7^{\circ} \times 7^{\circ}$ まで適用可能となっているが; 特に最近では これにエレクション・ジョイント型の片面自動溶接方式 が租合放されてとれらブロック溶接の近代化に役立って いる.

\section{3. 溶接の自動化率（溶接材料の 使用結果)}

表 1 は筆者の造船所においてすでに適用しているか， または将来適用しようとしている自動溶接法についてそ の溶接材料を溶接法別，ステージ別，継手の種類別およ び適用部材別の使用比率の变化を時代の推移により経験 的に示したものであり，とれにより溶接の自動化の程度 と推移を知ることができる。との結果をみると自動溶接 材料では1960年から1970年にかけて約 $8 \%$ の増加を示し ている，乙れは平板ブロックに拈けるサブマージ・アー ク溶接の適用範囲の拡大，曲り外板ブロックにおけるサ ブマージ・アーク溶接の適用，さらには立向自動溶接法 などの採用による増加とみなされる。しかしての間には 内容的に特筆すべきすのとして平板ブロックの板継ぎに おける片面自動溶接法の採用があったが、これは自動化 率のうえではあまり表面にあらわれてきていない，また 1970年以後においてはロ.ンジ・フレームの水平スミ肉溶 接にサブマージ・アーク溶接を採用する場合および杵組 みの立向スミ肉溶接にノンガス・アーク溶接を採用する 場合に自動化率は大きく増加する。さらにまた曲り外板 ブロックの板継ぎにおいてポジショナーを使用すること により全継手に対して自動溶接（片面溶接）の啇用を可 能とするが自動化率は $1 \%$ 程度の増加率を示すにすぎな い結果となっている。

\section{4. 溶接の自動化による節減工数}

\section{1 溶接工事量亡溶接アーク時間}

溶接工事㟟を評価する場合，ふつう船体にあってはま ず溶接長（あるいは継手長）が示され，さらにこれから 時間あたりの能率資料にもとづいて配員その他の計画が 行なわれる。一般には溶接工事量は溶接長（または継手 長)、であることが多い。しかしながら溶接長（または継 手長）といってあその継手にはスミ肉と突合せの 2 種類 があり，さらに前者は脚長あるいはのど厚，また後者は 使用鋼材の板厚により溶接能率はいちじるしく変化し, かつこれはいずれも溶接時の姿勢, 溶接法, 使用溶接棒 の種類と心線径, 溶接条件, 開先の状態などのいかんに
より大きく左右される：しかす船体の溶接長（または継 手長) は DW 100,000 ton 級の船で 400,000 m（継手 長で $200,000 \mathrm{~m}$ ) DW 200,000 ton 級の船で $600,000 \mathrm{~m}$ （継手長で $300,000 \mathrm{~m}$ ) を超えるぼう大なむのであるた め，以上のような諸種の条件が十分わかっていてもこれ をいちいち正確にまとめることの煩雑さのために，単に 工程を計画するには経験的な溶接長 (継手長) 一能率で 算定される力法の案外実用的なことから一般化しないで 今日にいたっている.しかし本論文においては船体溶接 工数の節減方法を, 現在考えられるととろの各種の自動 化によりこれらの効果を評価しようというのがねらいで あるから，ここでは当然前記の各種の因子を考慮した工 事量が必要となる．幸い溶接施工において標準で定めら れた方法によるかぎりアークを出している時間はいわゆ る機械時間の 1 種と考えられるから，これにある一定の

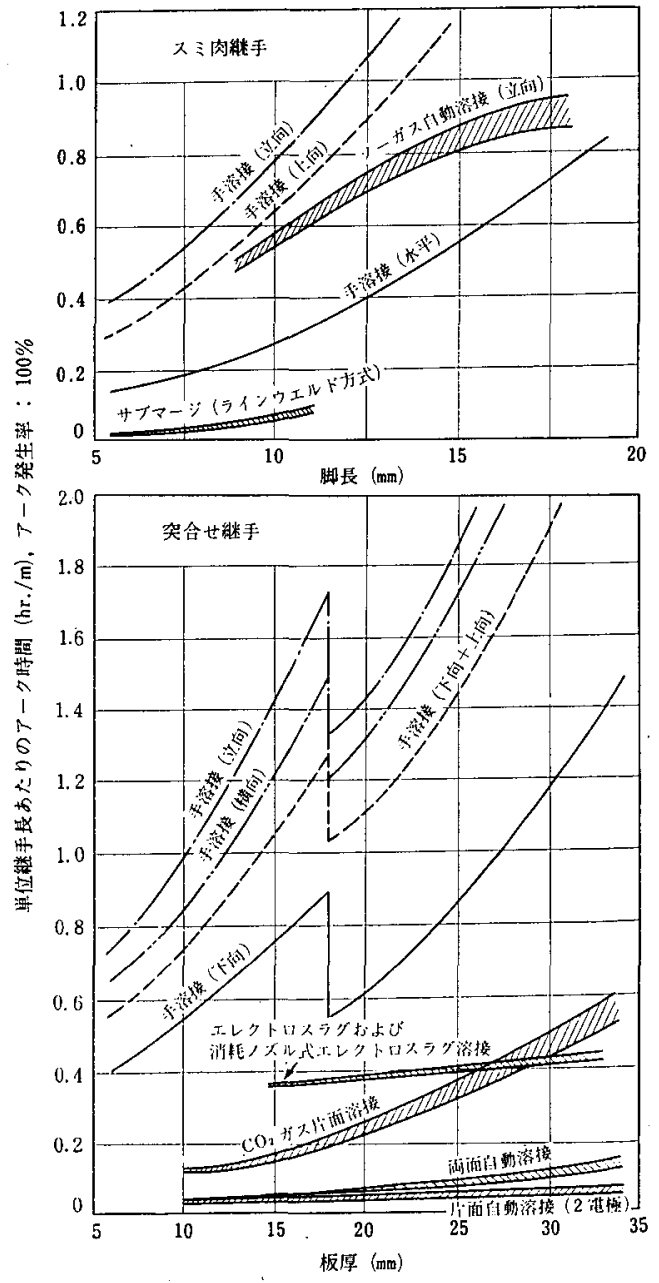

图一3 スミ肉拈よび突合せ継手に おりる各種溶接能率 
溶接条件を適用すれば，与えられた寸法（脚長または板 愿）の溶接継手を組立方法による溶接姿勢加ら判断して アーク発生率が 100\% のときの溶接時間を求めるととが できる. '図3の各图は筆者の使用している基本的溶接条 件を示す. 図の上側はスミ肉継手の場合であって手溶接 では水平, 立向, 上向の各姿勢に対して D4301（イルミ ナイト系）の溶接棒を使用して求めた場合のアーク時 間; . また自動溶接では立向の姿勢にノンガス.・アーク溶 接を, 水平にはライン・ウエルド式のサブマージ・アー ク溶接法を適用した場合のアーク時間を示す. 図の下側 は笑合せ継手の場合であり，手溶接では下向，水平，立
向，上向（ただじ両面とも上向で溶接する継手というの は事実上存在しないので実際には上向十下向となる）の 各姿勢に対して D4301 の溶接棒を使用して求めた宁一 ク時間を示す。また自動溶接で平板ブロックおよび曲り ブロックの下向きにはサブマージ・アーク溶接による片 面自動溶接法 (FCB 法は 2 電極, カタフラックス法の 場合は 2 または 3 電極）扣よび両面溶接法を, さらに立 向ではエレクトロスラグまたは消耗ノズル式エレクトロ スラグ溶接の場合をまた船体内構材（たとえばサイド ロンジ）のような向継手には $\mathrm{CO}_{2}$ ガス・アーク溶接 による片面自動溶接を用いて求めたアーク時間を示した
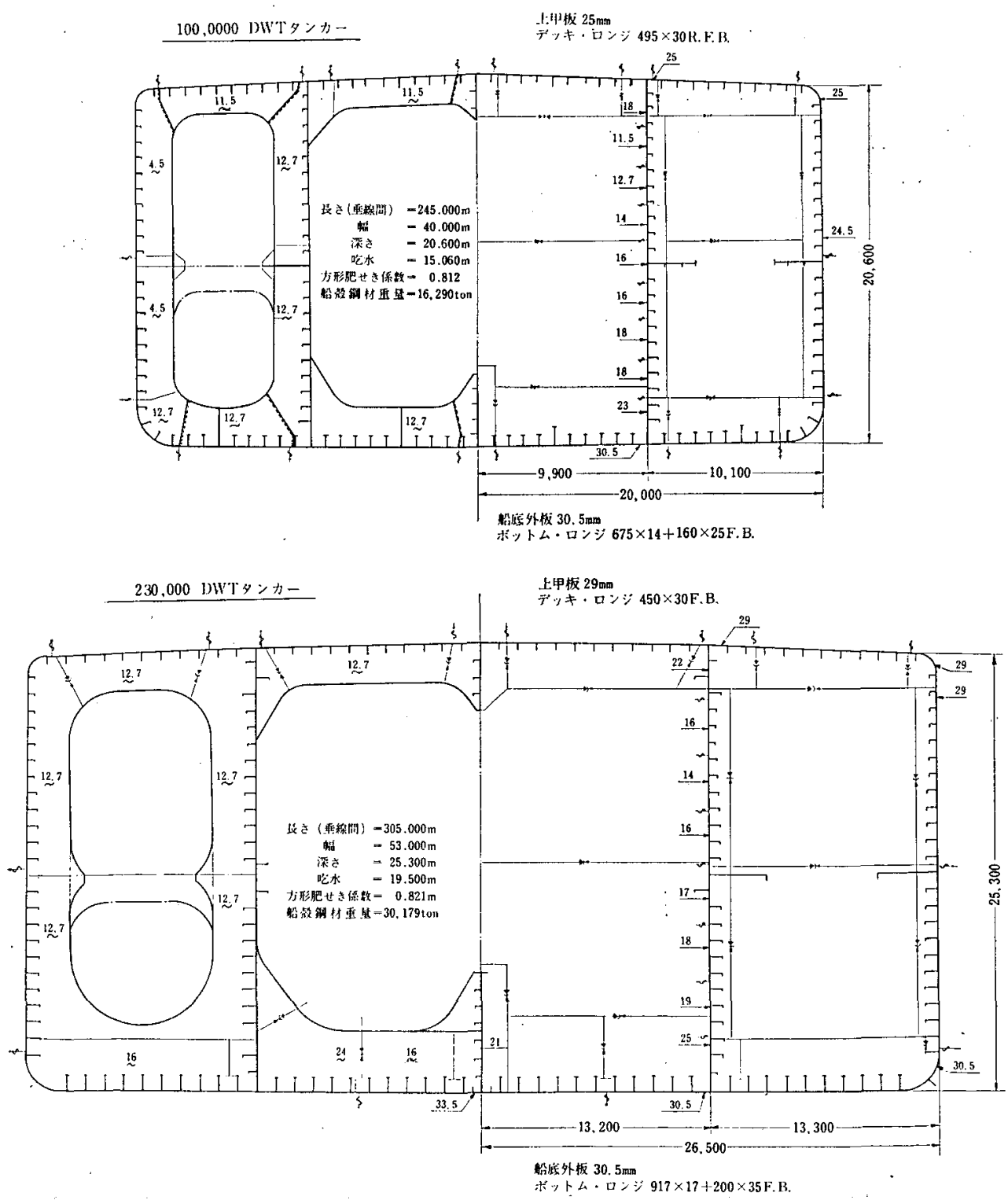

図一４大型船の中央横裁断面の例 
あのである。これにより開先は標準の状態にあるとし で：いっぽう別に求めたモデル船の継手長“(図 3 の場合 溶接長ではなく継手長をとうている）を種類と奖勢别に 適用すればアーク率.100\% の場合のアーク時間が求まる ことになる：ここではアーク率を地上工程においては50 \%，船台工程では35\%と仮定して以下計算を行なってい る.したがうて結局ての場合溶接時間＝計算による工数 =アーク時間 (ア-ク $100 \%$ の場合)

$\times \frac{100}{50 \text { (地上工程) または } 35 \text { (船台工程) }}$ として求めら れるとととなる。

\section{2 モデル船とアーク時間の算出法}

まずモデル船であるが，乙れについては筆者は DW 100,000 ton 型タンカーおよび DW 230,000 ton 型夕 ンカー（図4）を選んだ. 前者の場合は 1 隻分全区画に ついて溶接時間を算出したが，後者の場合は油槽区画全 体およびそれ以外の区画については 1 タンク分の溶接時 間より，これに適当な係数を莱じて推定值を出してい る. この推定の根拠は 2 種のモデル船の方形肥せき係数
(Cb) の大きさをくらべてとれてがほぼ等しかったでと (Cb 100,000/Cb 230;000=0.812/0,821 $\div 0.99$ ).になり， 両者の船型はほぼ相似形であると判断した。したがって DW 230,000 ton 型に扔ける油槽区画全体は油槽区画 全体の長さ(Ltp) 亡1タンク分の長さ (Lot) の比率 $(\mathrm{Ltp} / \mathrm{Lot}=4.30)$ を $\mathrm{DW} \cdot 230,000$ 型の 1 タンク分の溶 接時間に乗じて算出した: また油槽区画以外の区画につ いてす同様な考え方で DW 100,000 型の油槽区画以外 の区画之油槽区画全体のアーク時間の比率 (ATf \& a/ $\mathrm{AT} \mathrm{tp}=0.354)$ DW 230,000 ton 型の油槽区画全体 分の溶接時間に乗じて算出した。これらの計算において 使用したアーク時間は手溶接の場合を使用した。 また各 種自動溶接法適用個所に対する溶接時間の場合について あまったく同様な考え方でそれぞれ DW 100,000 ton 型の油槽区画全体のアーク時間と自動溶接の適用個所の ア一ク時間との比率を DW 230,000 ton 型の油槽区画 全体分の溶接時間に乘じて算出した。なお，推定值の誤 差をチェックするために, DW 230,000 ton 型タンカー の実際の継手長を求めた。 その絬果害際值は $329,179 \mathrm{~m}$

表一 2 非滨による溶接所要時間

アーク発生率 地上工程の場合 $50 \%$

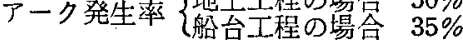

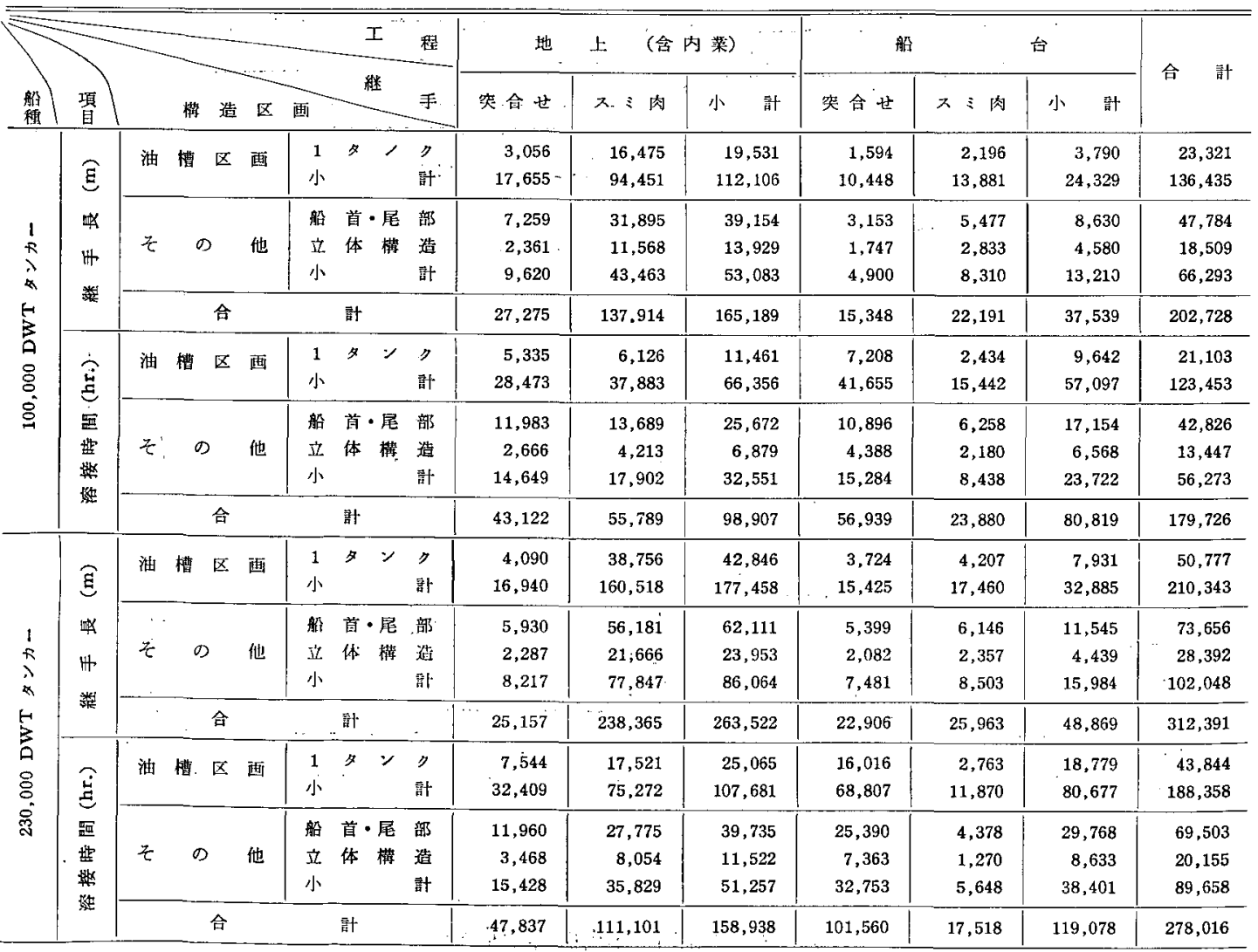


表一 3 溶接の自動化による溶接所要時間の変化

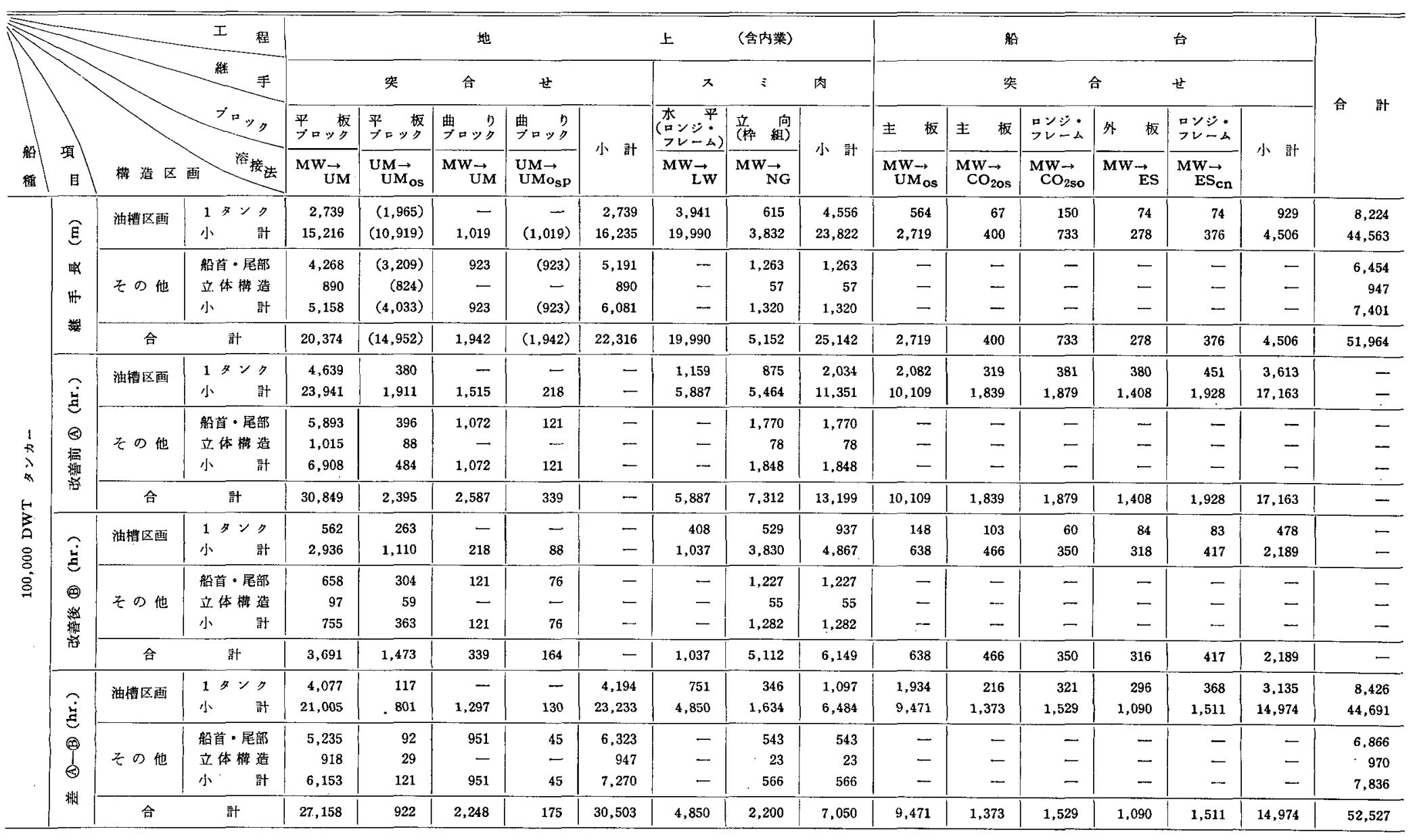




\begin{tabular}{|c|c|c|c|c|c|c|c|c|c|c|c|c|c|c|c|c|c|c|}
\hline \multirow{23}{*}{$\begin{array}{l}1 \\
R \\
\lambda \\
0 \\
0 \\
0 \\
0 \\
0 \\
0 \\
0\end{array}$} & \multirow{5}{*}{$\begin{array}{l}\widehat{E} \\
\text { 凅 } \\
\text { H } \\
\text { W }\end{array}$} & 油槽区画 & $\begin{array}{l}1 \text { タンク } \\
\text { 小 計 }\end{array}$ & $\begin{array}{r}4,017 \\
17,273\end{array}$ & $\begin{array}{r}(3,060) \\
(13,158)\end{array}$ & $\overrightarrow{1,591}$ & $\begin{array}{c}- \\
(1,591)\end{array}$ & $\begin{array}{r}4,017 \\
18,864\end{array}$ & $\begin{array}{r}9,454 \\
40,652\end{array}$ & $\begin{array}{r}3,086 \\
13,270\end{array}$ & $\begin{array}{l}12,540 \\
53,922\end{array}$ & $\begin{array}{r}902 \\
3,879\end{array}$ & $\begin{array}{l}197 \\
847\end{array}$ & $\begin{array}{l}212 \\
912\end{array}$ & $\begin{array}{l}150 \\
645\end{array}$ & $\begin{array}{l}104 \\
447\end{array}$ & $\begin{array}{l}1,565 \\
6,730\end{array}$ & $\begin{array}{l}18,122 \\
79,516\end{array}$ \\
\hline & & \multirow{3}{*}{ その他 } & \multirow{2}{*}{$\begin{array}{l}\text { 船首・尾部 } \\
\text { 立体構 浩 }\end{array}$} & 6,115 & $(4,658)$ & 421 & (421) & 6,536 & - & 4,698 & 4,698 & - & - & - & - & - & $\ldots$ & \multirow{3}{*}{$\begin{array}{r}11,234 \\
1,106 \\
12,340\end{array}$} \\
\hline & & & & 916 & (903) & - & - & 916 & - & 190 & 190 & - & - & - & - & - & - & \\
\hline & & & 小 計 & 7,031 & $(5,561)$ & 421 & (421) & 7,452 & - & 4.888 & 4,888 & - & - & - & - & - & - & \\
\hline & & \multicolumn{2}{|r|}{ 計 } & 24,304 & 18,719 & 2,012 & $(2,012)$ & 26.316 & 40,652 & 18,158 & 58,810 & 3,879 & 847 & 912 & 645 & 447 & 6,730 & \multirow{3}{*}{$\begin{array}{r}91,856 \\
-\end{array}$} \\
\hline & \multirow{6}{*}{ 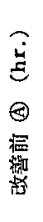 } & \multirow{2}{*}{ 油槽区画 } & \multirow{2}{*}{$\begin{array}{l}1 \text { タンク } \\
\text { 小 部 }\end{array}$} & 7,338 & 688 & - & - & - & 2,927 & 4,768 & 7,695 & 4,145 & 1,322 & 598 & 830 & 806 & 7,701 & \\
\hline & & & & 31,553 & 2,958 & 2,638 & 319 & - & 12,586 & 20,502 & 33,088 & 17,824 & 5,685 & 2,571 & 3,569 & 3,466 & 33,115 & \\
\hline & & \multirow{3}{*}{ その他 } & 船首・尾部 & 11,170 & 1,047 & 631 & 78 & - & - & 7,258 & 7,258 & - & - & - & - & - & - & - \\
\hline & & & 立体權造 & 1,126 & 113 & - & - & - & - & 295 & 295 & - & - & - & - & - & - & - \\
\hline & & & 小 & 12,296 & 1,160 & 631 & 78 & - & - & 7,553 & 7,553 & $\ldots$ & - & - & - & - & - & - \\
\hline & & 合 & 計 & 43,849 & 4,118 & 3,269 & 397 & - & 12,586 & 28,055 & 40.641 & 17,824 & 5,685 & 2,571 & 3,569 & 3,466 & 33,115 & - \\
\hline & & 油槽区画 & $1 タ ン ク$ & 813 & 276 & - & - & - & 1,063 & 3,368 & 4,431 & 251 & 253 & 124 & 172 & 232 & 1,032 & - \\
\hline & $\dot{z}$ & & 小 & 3,496 & 1,187 & 319 & 144 & - & 4,571 & 14,482 & 19,053 & 1,079 & 1,088 & 533 & 740 & 998 & 4,438 & - \\
\hline & ค & & 船首・・尾部 & 1,238 & 420 & 78 & 52 & - & - & 5,127 & 5,127 & - & - & - & - & - & - & - \\
\hline & 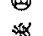 & その他 & 立体满造 & 97 & 51 & - & - & - & - & 242 & 242 & - & - & - & - & - & - & - \\
\hline & 塮 & & & 1,335 & 471 & 78 & 52 & - & - & 5,369 & 5,369 & - & - & - & - & - & -- & - \\
\hline & & 合 & 計 & 4,831 & 1,658 & 397 & 196 & - & 4,571 & 19,851 & 24,422 & 1,079 & 1,088 & 533 & 740 & 998 & 4,438 & - \\
\hline & & 油槽区画 & 1 タンク & 6,525 & 412 & - & - & 6,937 & 1,864 & 1,400 & 3,264 & 3,894 & 1,069 & 474 & 658 & 574 & 6,669 & 16,870 \\
\hline & 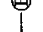 & & 小 訪 & 28,057 & 1,771 & 2,319 & 175 & 32,322 & 8,015 & 6,020 & 14,035 & 16,745 & 4,597 & 2,038 & 2,829 & 2,468 & 28,677 & 75,034 \\
\hline & 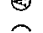 & & 船首・尾部 & 9,932 & 627 & 553 & 26 & 11,138 & - & 2,131 & 2,131 & - & - & - & - & - & - & 13,269 \\
\hline & $\dot{s}$ & その他 & 立体權 造 & 1,029 & 62 & $\rightarrow$ & - & 1,091 & - & 53 & 53 & - & - & - & - & - & - & 1,144 \\
\hline & & & 小 & 10,961 & 689 & 553 & 26 & $12,22 \Omega$ & - & 2,184 & 2,184 & - & - & - & - & - & - & 14,413 \\
\hline & & 合 & 計 & 39,018 & 2,460 & 2,872 & 201 & 44,551 & 8,015 & $8,2 C 4$ & 16,219 & 16,745 & 4,597 & 2,038 & 2,829 & 2,468 & 28,677 & 89,447 \\
\hline
\end{tabular}

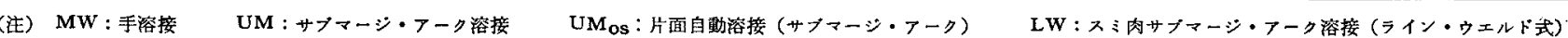
NG : ルンガス・アーク溶接
$\mathrm{CO}_{208}:$ 片面自動溶接 $\left(\mathrm{CO}_{2} \cdot 7-\eta\right)$
ES : メレクトロスラグ溶接
$\mathrm{ES}_{\mathrm{cn}}$ : 消耗バル式エレクトロスラグ容接 
であるのに対して推定值は $312,391 \mathrm{~m}$ であり，その差 は $16,788 \mathrm{~m}$ (実際の場合の約5.1\%) であったので推定 值はほぼ実際值に近いと判断した。

\section{3 自動化による節減工数の計算例}

前記の 2 種のモデル船を用いた計算においては自動溶 接法を採用したてとによる経済性を険討する必要がある から，ての点を考慮し，まずあらゆる継手をすべて手溶 接で行なった場合のアーク時間を前記の溶接条件をむと にして算出した，ての場合溶接姿勢は自動溶接法の場合 とまったく同一条件としているし，またプリエレクショ ンについては考虑しなかった（表 2)，つぎに各種自動 溶接法をモデル船に適用する場合のそれぞれのアーク時 間とこれに対応する継手を手溶接で行なった場合のアー ク時間を求めた，両者の差が自動化による工数の節減効 果之なる，各種自動化の工数節減効果を表 3 k示す．乙 の表に示した各種の自動溶接法が適用されると最終的に は手溶接の場合にくらべて DW 100,000 ton 型で 1 隻 あたり $52,527 \mathrm{hr}$. (とのうち地上工程は $37,553 \mathrm{hr}$.), DW 230,000 ton 型では $89,447 \mathrm{hr}$. (とのうち地上工 程は $60,770 \mathrm{hr}$.) の節減ができることになる.したがっ て1隻建造するのに要する全溶接工数は.DW 100,000 ton 型の場合 $127,199 \mathrm{hr}$., DW 230,000 ton 型の場合で 188, 569 hr. となり，その節娍効果を比率で表わすと手 溶接の場合にくらべて DW 100,000 ton 型で約 29\%, DW 230,000 ton 型で約 $32 \%$ となる. しかしながら平板 ブロックおよび曲りブロックにおける片面自動溶接の側 からみると，直接的な工数節減というととでとらえると
片面自動溶接法の適用に上る工数節減勃果は. 手溶接加 ら両面自動溶接に変ったときの効果にくらべてはるかに 小さいことを示している.

\section{5. 自動化の今後の問題点}

筆者はこれまで主として溶接の自動化の手段とてれに よる直接的な省力効果と自動化率を通じて溶接自動化 の経済的効果を論じてきたが，今後は単に自動化比率の 增大あるいはてれによる表面的なアーク時間の節減のみ にとだわることなく，たとえば半自動溶接を全自動化さ せるとか片面溶接にするなどの例にみられるごとく作業 時の熟練要素を除去するとか, 余分な工程を省略するな どの諸工夫がますます必要となるであろう．そしてての 観点からすれば既述の曲り外板の片面自動溶接法や，ま た船底外板のバットに下部から狭腺開先溶接法を上向姿 勢で使用するなどの各種の方法の実用化が必要となる. これらはいずれも手のてんだ費用のかかるすので直接的 な節減工数だけで議論できないすのもあるが，その反面 組立精度の向上と工程の直接化を通じててれらの施工法 に上る間接的省力効果が非常に大きいと考えられ, 近代 化が進めば進むほどこの種の傾何はますます大きくなっ てくるであろう.さらに，ての論文ではアーク発生率を 地上工程では50\%，船台工程では35\%としているが，と の值は自動化が進み造船業を“production type” へ発 展させるととにより増大する可能性があることを忘れて はならない。 